\title{
RELASI MITOS, DAN AGAMA SEBAGAI MEDIA PENINGKATAN EKONOMI PRODUKTIF DALAM TRADISI “TEBOKAN" DI DESA KALIPUTU KOTA KUDUS
}

\author{
Saifuddin \\ Dosen Sekolah Tinggi Agama Islam Negeri Kudus (STAIN) Kudus \\ Saifud_din@yaboo.com
}

\begin{abstract}
"Tebokan" was the history of jenang production processes that was visualized on cultural carnival. It was one of the place where the relationship of religious traditions and the myth of local society became a new spirit to increase the economy of the community. This research was based on interpretative perspective to religious behaviors such as done by Clifford Geertz. Therefore this research used qualitative method. This study found the cultural illustrations where the relationship of myth, religious tradition, and the social structure was able to activate spirit of productivity in the Kaliputu Society as a central of jenang Production in Kudus. Both of these systems of meaning were able to present three important spirits, those are innovative, identity affirmation, and work ethic.
\end{abstract}

Key words: "Tebokan” Tradition, Myth, Religion, Productivity.

\begin{abstract}
Abstrak
"Tebokan" adalah sebuab visualisasi sejarah proses produksi jenang yang direpresentasikan lewat karnaval budaya. Sebuab tradisi yang menjadi sebuab "arena" dimana bubungan antara tradisi agama dan mitos masyarakat setempat menjadi sebuah spirit baru dalam meningkatkan perekonomian masyarakat. Penelitian ini didasarkan pada pemaknaan atas perilaku religious, seperti halnya yang pernab dilakukan oleb Cifford Geertz. Dengan demikian penelitian ini menggunakan pendekatan kualitatif. Penelitian ini menemukan sebuab gambaran cultural dimana relasi antara mitos, tradisi agama, dan struktur social, mampu memberikan spirit produktif dalam masyarakat Desa Kaliputu sebagai sentra produksi jenang di Kabupaten Kudus. Mitos dan tradisi agama sebagai system makna tersebut mampu menghadirkan tiga spirit produktif, yakni spirit inovatif, penegasan identitas, dan etos kerja yang tinggi.
\end{abstract}

Kata kunci: Tradisi Tebokan, Mitos, Agama, Produktifitas. 


\section{Pendahuluan}

Salah satu makanan khas di Kabupaten Kudus adalah Jenang, yakni sejenis makanan kecil yang terbuat dari tepung ketan dan gula Jawa. Sebagai sebuah ikon makanan di kota Kudus, jenang telah mampu menyumbangkan perannya dalam peningkatan perekonomian masyarakat di Kabupaten Kudus, khususnya di Desa Kaliputu Kecamatan Kota. Data yang dihimpun oleh penulis menunjukkan bahwa dari total penduduk di Desa Kaliputu yang berjumlah 3466 warga, 960 warga terserap dalam industry jenang sebagai karyawan. Data tersebut sangat realistis karena di desa Kaliputu terdapat 48 industri jenang bersekala besar maupun kecil, dan setiap industry menyerap 15 sampai 50 karyawan.

Jenang bagi masyarakat Kudus bukan hanya sekedar makanan yang dibuat untuk memenuhi kebutuhan fisik manusia semata, tetapi jenang juga memiliki nilai sejarah yang amat panjang, khususnya bagi warga Desa Kaliputu sehingga terdapat mitos yang kemudian diangkat sebagai bagian dari spirit produktif masyarakat desa setempat. Sejarah asal mula pembuatan jenang inilah yang kemudian divisualisasikan dalam sebuah karnaval budaya yang disebut Tradisi "tebokan".

Kirab Tebokan merupakan salah satu bentuk pelestarian tradisi dan sejarah pembuatan jenang. Hal itu tidak terlepas dari kisah Mbah Dempok dan cucunya. Konon, ketika Mbah Dempok Soponyono sedang bermain burung dara di tepi Sungai Kaliputu, cucunya tercebur dan hanyut. Meski tertolong, cucu Mbah Dempok diganggu Banaspati, makhluk halus berambut api. Sunan Kudus menyimpulkan cucu Mbah Dempok telah tiada, tetapi Syekh Jangkung menyatakan cucu Mbah Dempok mati suri. Untuk membangunkannya, Syekh Jangkung meminta ibu-ibu membuat jenang bubur gamping. Mitos itulah yang melatarbelakangi berkembangnya industri jenang Kudus, dan mitos itu pulalah yang menginspirasi ibu-ibu Desa Kaliputu bekerja di industri jenang kudus.

Warga Desa Kaliputu melaksanakan tradisi Tebokan tersebut pada peringatan awal tahun baru Islam tiap-tiap tahun. Lamanya rentang waktu untuk mempertahankan tradisi tersebut merupakan keunikan yang patut untuk dicermati. Perubahan masyarakat yang 
terjadi selama puluhan dasawarsa tersebut tentu saja ikut mewarnai perkembangan tradisi tebokan ini, karena sesakral apapun sebuah tradisi, ia adalah sebuah hasil dari proses berfikir manusia yang didasarkan atas kearifan local (local wisdom) dan yang paling penting adalah lingkungan social maupun budaya yang menaunginya. Apa yang terjadi pada acara tebokan adalah contoh nyata bagaimana sebuah tradisi masyarakat berdialog dengan perkembangan budaya khususnya budaya modern seperti sekarang ini.

Dalam konteks tradisi tebokan hubungan antara tradisi agama dan mitos masyarakat setempat menjadi sebuah spirit baru dalam meningkatkan perekonomian masyarakat. Hal itu karena keberadaan jenang yang menjadi ikon cerita rakyat tersebut menginspirasi masyarakat untuk menjadikannya sebagai produk ungggulan tidak hanya di Desa Kaliputu tetapi juga sebagai ikon kuliner di Kabupaten Kudus. Kirab tradisi tebokan akhirnya menjadi sebuah moment penting dalam melestarikan tradisi local sekaligus menjadi ajang promosi produk local dan juga menjadi salah satu asset pariwisata di Kabupaten Kudus.

Persoalan besar yang justru muncul adalah bagaimana proses dialektika antara tradisi agama dengan lingkungan social budaya tersebut dapat berjalan secara sempurna. Terdapat tiga asumsi yang kemudian akan terjadi dan menimpa setiap tradisi, baik itu tradisi keagamaan maupun non keagamaan, jika harus berbenturan dengan proses social yang dinamis (modernitas). Pertama, ada resistensi yang dilakukan oleh tradisi, dimana tradisi cenderung menjauhi hal-hal yang ada di luar pakem. Akibatnya adalah tradisi tersebut semakin hilang ditelan oleh dinamika perubahan yang begitu deras, meminjam istilah Antony Giddens, perubahan tersebut layaknya seperti jugernout, truk besar yang bergerak tanpa kendali. (Lemert,1999: 488)

Asumsi yang kedua adalah adopsi besar-besaran dilakukan oleh sebuah tradisi, sehingga cenderung menghilangkan pakem dari tradisi tersebut. Pada kasus seperti ini, tradisi masih eksis hanya pada permukaannya saja, akan tetapi secara substansial tradisi tersebut kehilangan maknanya. Proses seperti inilah yang dalam pemikiran sosiologi modern dikenal dengan proses sekularisasi. Max Weber misalnya menggambarkan akibat dari modernisasi adalah sparasi wilayah-wilayah nilai dan tatanan kehidupan, wilayah nilai 
ekonomi, etika, hukum yang sebelumnya terstruktur dengan satu prinsip kesatuan dalam dunia religius, kemudian mulai dilepaskan oleh rasionalisme pencerahan (Budiman, 1998: 42).

Ketiga, ada upaya adaptasi sistemik antara tradisi dan dinamika perubahan, sehingga memunculkan jenis tradisi yang betulbetul baru. Dialektika antara tradisi dan perubahan ini tidak hanya percampuran yang eklektis semata, tetapi merupakan budaya baru yang muncul dari bertemunya berbagai agency yang ada di dalam pentas peradaban. "Bayi" peradaban ini sering kali disebut sebagai budaya hibrida (bybrid culture) (Lemert, 1999: 628). Budaya hibrida ini banyak muncul ke permukaan seiring dengan proses globalisasi, dimana ruang-ruang budaya terbuka lebar, sehingga sekat-sekat budaya yang dahulu menjadi penghalang interaksi dan komunikasi antar budaya menjadi sirna.

Mitos tradisi tebokan yang berkembang dikalangan masyarakat Desa Kaliputu tentu saja tidak dimaknai secara tunggal oleh warga setempat, karena pada dasarnya manusia selalu memiliki kemampuan untuk memaknai segala peristiwa (animal symbolicum). Penelitian ini berupaya untuk menjawab persoalan bagaimana pemaknaan mitologis dan religious warga Desa Kaliputu, dan bagaimana pemaknaan tersebut menjadi media untuk peningkatan ekonomi produktif masyararakat setempat?.

Secara teoritik, penelitian ini diharapkan mampu memperkaya khazanah krirtik budaya seiring dengan perkembangan ilmu, teknologi, dan trend pengaruh arus globalisasi, yakni peran dari setiap dimensi struktur melalui agen maupun subjek di dalamnya. Praktisnya, melalui rekonstruksi pemaknaan sebuah tradisi diharapkan dapat memberikan inspirasi kepada pemerintah dalam pengambilan kebijakan (public policy) untuk meningkatkan produktifitas masyarakat.

\section{Mitos (Tebokan) dalam Bingkai Agama Islam Jawa}

Istilah "tebokan" berasal dari kata tebok yang berarti nampan yang terbuat dari anyaman bambu. Nampan ini seringkali digunakan oleh masyarakat sebagai tempat untuk menaruh makanan atau sebagai alat untuk menyajikan makanan. Tradisi tebokan merupakan visualisasi sejarah yang menggambarkan bagaimana makanan jenang 
itu muncul dan membawa kesejahteraan bagi masyarakat setempat.

Tradisi yang kemudian dipentaskan dalam karnaval budaya tersebut tentu saja mempunyai makna yang beragam dikalangan masyarakat setempat. Jika tradisi tebokan ini diasumsikan sebagai sebuah teks, maka dalam konteks masyarakat modern teks tersebut hanyalah sebuah symbol yang secara kontekstual tidak rasional, meskipun mempunyai peran dalam kehidupan social, maka perilaku simbolik tersebut seringkali disebut dengan istilah mitos. Mitos bagi Muhsin Jamil diartikan sebagai sebuah angan-angan social dan cita-cita kolektif yang selalu menggerakkan sebagaian masyarakat (Jamil, 2005: 181). Bagi Malinowski (1954: 101), mitos diartikan sebagai media pengungkapan dan merumuskan kepercayaan, melindungi dan memperkuat moralitas, menjadi efisiensi dan ritus, serta memberi peraturan praktis menuntun manusia. Dilihat dari fungsinya mitos menjadi satu kesatuan dengan agama yang memainkan peran penting dalam kehidupan manusia.

Di dalam tradisi neo Marxian mitos dianggap sebagai struktur penandaan yang mendistorsi realitas, seperti yang dikemukakan oleh Roland Barthes yang dikutip oleh Idy Subandi Ibrahim;

Mitos mengubah bias dan prasangka menjadi sejarah, namun ia adalah sejarah yang sudah "dibengkokkan"(Barthes, 2007: xiii)

Maka dari itu kritik terhadap budaya kontemporer yang penuh dengan mitos, sangat diperlukan. Menjadi kritis bukan hanya sekedar menemukan makna rahasia dibalik karya atau kebenaran di masa silam, melainkan membangun pemahaman untuk zaman sekarang. Pemahaman terhadap mitos yang terdapat dalam tradisi tebokan dengan demikian dapat dimaknai sebagai upaya pembentukan spirit produktif melalui rekonstruksi makna tradisi local yang berkelindan dengan ajaran agama Islam.

Pembentukan spirit produktif atas dasar pemaknaan system nilai tersebut sudah berlangsung cukup lama semenjak tradisi local Jawa bertemu dengan ajaran Islam yang datang lebih kemudian. Konstitusi Islam lokal sebagai sistem keagamaan dan social terbentuk melalui seperangkat konsep yang dipakai untuk menafsirkan unsur-unsur tradisi yang diterima dan pengetahuan budaya serta pengetahuan keagamaan local. Di Jawa penafsiran 
Islam sebagai suatu tradisi dan system social selalu terkait dengan empat Prinsip, yakni keesaan Allah, pembedaan sufistik antara makna lahir dan makna bathin, hubungan antara hamba dan Tuhan (manunggaling kawula gusti), dan kesamaan antara mikrokosmos dan makrokosmos (Woodward, 1999: 101).

Pada prinsip yang terakhir inilah terdapat satu pemahaman tentang sebuah persoalan, siapa yang memperantarai antara mikrokosmos dan makrokosmos?. Para elit Jawa berpedoman bahwa yang menjadi jembatan antara keduanya adalah Sultan, sedangkan para santri Jawa mengatakan Ulama'-lah yang menjadi jembatan antara keduanya. Para mistikus Jawa mengatakan yang menjadi jembatan antara mikrokosmos dan makrokosmos adalah diri sendiri, karena didalam diri bersemayam sifat ketuhanan, atau yang dikenal mistikus sufi dengan istilah "manunggaling kawula gusti". Pemaknaanpemaknaan seperti inilah yang mewarnai tradisi "tebokan" di zaman kontemporer seperti sekarang ini menjadi variatif.

\section{Memahami Makna Simbolik: Sebuah Ikhtiar Pemahaman Teoritik}

Dalam kajiannya tentang agama, Clifford Geertz menguraikan tentang makna agama yang berarti suatu system symbol yang bertindak untuk memantapkan perasaan-perasaan (moods) dan motivasi-motivasi secara kuat, menyeluruh, dan bertahan lama pada diri manusia, dengan cara memformulasikan konsepsi-konsepsi mengenai hukum (order), yang berlaku umum berkenaan dengan eksistensi manusia. Konsepsi-konsepsi ini selalu diselimuti dengan suatu aura tertentu yang mencerminkan kenyataan, sehingga perasaan-perasaan dan motivasi-motivasi tersebut nampak unik dan nyata (Geertz, 1973: 87).

Sistem makna yang terhampar dalam setiap ruang budaya terbentuk melalui serentetan peristiwa baik itu terkait dengan hal-hal yang bersifat alamiah ataupun hal-hal yang terkait dengan pengalaman subjektif. Mitos dan agama yang menurut Geertz adalah bagian dari system simbolik dengan demikian berpotensi untuk dimaknai oleh masyarakat secara beragam sesuai dengan dimansi ruang dan waktu. 
Tanda (sign) atau pesan simbolik yang didemonstrasikan dalam karnaval "tebokan" misalnya, memamg tidak serta merta dapat dimaknai secara seragam oleh khalayak, karena pemaknaan atas tanda selalu terkait dengan latar belakang pembaca tanda. Jika realitas budaya ini dianggap sebagai sebuah teks, maka pemaknaan atas teks tersebut tentu terkait dengan konteks. Dalam kajian hermeneutika, keberadaan atau eksistensi manusia ditentukan oleh bagaimana dia memahami dan memaknai tanda kehidupan. Bagi Hans Georg Gadamer, sorang ahli hermeneutika dari Jerman, didalam memaknai realitas ataupun teks, seorang penafsir harus menghidupkan atau memproduksi makna yang terkandung dalam teks tersebut, sehingga teks tersebut menjadi kaya makna (Nasiful Atho', 2003:136) .

Bagi Gadamer, manusia mempu memahami dan memaknai realitas atau teks, karena ia mempunyai tradisi. Karena tradisi merupakan bagian dari pengalaman kita, maka tidak ada pengalaman kita yang berarti tanpa mengacu pada tradisi. Hal ini mengandung arti bahwa untuk memaknai sebuah teks atau realitas orang dituntut untuk menyingkap adanya kebenaran, dan untuk menyingkap kebenaran itu harus mengacu pada tradisi bukan pada metode ataupun teori. Apa yang terpampang dalam karnaval "tebokan" adalah sebuah teks budaya yang kaya akan makna sehingga khalayak bisa menafsirkannya sesuai dengan tradisi yang dimilikinya.

Objek-objek yang muncul diatas tentu saja bukan suatu yang natural dalam kemunculannya, tetapi saling terkait antara satu dengan yang lainya. Ibarat sebuah teks, apa yang kita lihat dihadapan kita adalah isyarat-isyarat atau tanda-tanda yang mau tidak mau harus kita baca dan kita maknai isyarat tersebut. Seperti halnya ketika kita melihat mobil, maka objek mobil tersebut mewartakan kepada kita tentang status pemiliknya. Dengan lain perkataan memaknai adalah satu hal yang sangat penting dalam kehidupan kita, dan merefleksikan objek tersebut adalah sebuah keniscayaan, hal inilah yang seringkali disebut dengan semiologi, yakni ilmu tentang pesan-pesan social, pesan-pesan cultural, dan lain sebagainya (Barthes, 2007:265).

Cara seseorang untuk merepresentasikan dirinya dengan symbol tertentu di maknai sebagai representasi symbol kebudayaan 
yang di belakangnya dipenuhi serentetan peristiwa dan kejadian kebudayaan yang membentuk pribadi bahkan struktur komunitas orang tersebut. Representasi symbol yang terjadi dalam sebuah perayaan kebudayaan merupakan salah satu bentuk atau cara bagaimana sebuah kelompok mengkomunikasikan makna identitas budaya kepada orang lain dalam menentukan posisi mereka dalam masyarakat inilah yang oleh Pierre Bourdieu disebut sebagai distingsi yang didasari oleh keseragaman habitus (Haryatmoko, 2003).

Menurut Bourdieu, keseragaman habitus dalam suatu kelompok menjadi dasar perbedaan gaya hidup dalam suatu masyarakat. Gaya hidup dipahami sebagai keseluruhan selera, kepercayaaan ,dan praktek sistematis yang menjadi suatu kelas, yang di dalamnya adalah opini politik, keyakinan filosofis, keyakinan moral, selera estetis, dan juga makanan, pakaian juga budaya. Reproduksi spirit produktif melaui proyek habitus ini dilakukan secara rumit dan epistemic.

\section{Metode Penelitian.}

Penelitian ini difokuskan pada dua hal. Pertama, ide atau gagasan, pandangan, dan penilaian yang ditujukan bagi terbentuknya rekayasa kultural, diwujudkan dalam bentuk symbol-simbol cultural, seperti miniature menara Kudus, visualisasi proses produksi, dan lain-lain. Kedua, bagaimana proses pembentukan makna lewat representasi symbol-simbol cultural tersebut. Dari kedua persoalan tersebut, fokus utama yang harus dieksplorasi adalah system kognisi atau pemahaman seluruh komponen masyarakat, dari mulai elit local sampai massa atau khalayak yang menjadi subjek tradisi. Atas dasar pertimbangan itu, maka penelitian ini menggunakan metode kualitatif. Penelitian ini berusaha menjawab pertanyaan yang menekankan bagaimana pikiran dan pengalaman sosial diciptakan dan diberi arti. Berbeda dengan metode kuantitatif yang menekankan pengukuran dan analisis hubungan kausalitas antara variabel, bukan menekankan untuk melihat proses (Salim, 2001: 11).

Dalam studi ini, penelitian kualitatif akan dioperasikan melalui analisis deskriptif, dengan melakukan reinterpretasi objektif 
tentang fenomena sosial yang terdapat dalam permasalahan yang diteliti, (Vredenberg, 1986: 34) yang dalam hal ini adalah proses pembentukan makna dalam tradisi kirab tebokan. Jadi pergerakannya tidak hanya sebatas pengumpulan dan penyusunan data, tapi mencakup analisis dan interpretasi symbol-simbol budaya yang dipentaskan (Surachmad, 1970: 131).

\section{Analisis}

\section{Realitas Upacara Tebokan}

Kirab Tebokan merupakan salah satu bentuk pelestarian tradisi dan sejarah pembuatan jenang. Hal itu tidak terlepas dari kisah Mbah Dempok dan cucunya. Konon, ketika Mbah Dempok Soponyono sedang bermain burung dara di tepi Sungai Kaliputu, cucunya tercebur dan hanyut. Meski tertolong, cucu Mbah Dempok diganggu Banaspati, makhluk halus berambut api. Sunan Kudus menyimpulkan cucu Mbah Dempok telah tiada, tetapi Syekh Jangkung menyatakan cucu Mbah Dempok mati suri. Untuk membangunkannya, Syekh Jangkung meminta ibu-ibu membuat jenang bubur gamping. Mitos itulah yang melatarbelakangi berkembangnya industri jenang Kudus. Mitos itu pulalah yang menginspirasi ibu-ibu Desa Kaliputu bekerja di industri jenang kudus.

Selain cerita di atas, terdapat versi lain dari sejarah jenang kudus, yaitu apa yang diceritakan oleh salah satu pengusaha jenang terbesar di Kudus, bahwa menurut cerita rakyat, jenang kudus lahir ketika Sunan Kudus (salah satu anggota Wali Sanga) menguji kesaktian salah satu muridnya yang bernama Syech Jangkung alias Saridin dengan menyuruhnya memakan bubur gamping di tepi Sungai Gelis di wilayah Desa Kaliputu. Gamping adalah salah satu hasil tambang yang sebagian besar mengandung kalsium karbonat dan biasanya dicampur dengan semen untuk digunakan sebagai bahan pembuatan tembok, sehingga tidak layak dikonsumsi oleh tubuh manusia. Ternyata Saridin tetap segar bugar sehingga Sunan Kudus berucap, "Suk nek ono rejaning jaman wong Kaliputu uripe seko jenang. "Artinya lebih kurang, jika suatu saat kelak sumber kehidupan warga Desa Kaliputu berasal dari usaha pembuatan jenang. 
Terlepas dari versi yang mana kebenaran cerita asal usul makanan jenang, yang jelas makanan jenang sekarang menjadi salah satu produk unggulan tidak hanya di Desa Kali putu, tetapi juga di Kabupaten Kudus. Selain itu jenang sekarang sudah menjadi tumpuan hidupp bagi banyak warga khususnya di Desa Kaliputu. Di Desa Kaliputu terdapat 48 industri jenang skala besar maupun kecil. Jenang Kudus Mubarok yang berada di lain desa pun cikal bakal industrinya berangkat dari Desa Kaliputu dan berkembang menjadi yang produsen jenang kudus yang terbesar di kabupaten kudus. Setiap industri jenang di desa tersebut menyerap 15-50 tenaga kerja. Setidaknya ada sekitar 960 warga yang bekerja di sektor industri jenang.

Jenang merupakan ekonomi unggulan Desa Kaliputu sekaligus Kudus. Melalui industri jenang inilah setiap hari asap dapur warga selalu mengepul. Oleh karena itu, supaya kisah jenang diketahui lintas generasi di Kudus, Suyadi menambahkan, Kirab Tebokan akan dilakukan terus setiap tahun dengan harapan generasi berikutnya tidak akan malu bekerja sebagai pembuat jenang serta mau melestarikan makanan khas Kudus itu.

Lewat makanan jenang inilah Desa Kaliputu dikenal luas, tidak hanya di Kabupaten Kudus, tetapi juga diluar daerah Kudus, sehingga jenang menjadi ikon Desa bahkan ikon kuliner Kabupaten Kudus. Hal itu terpapar dengan jelas ketika peneliti berkunjung ke Balai Desa Kaliputu, suguhan unik yang disuguhkan kepada peneliti dan juga para tamu lainnya adalah jenang yang ditaruh diatas nampan kecil terbuat dari bambu, wadah itulah yang dinamakan tebok (Pen.) Maka tidak salah jika Desa Kaliputu menjadi salah satu desa wisata budaya di Kabupaten Kudus, dan sekaligus menjadi pilot project pengembangan budaya dan pariwisata yang dijadikan sebagai asset daerah.

Realitas upacara "tebokan" dengan demikian adalah sebuah moment dimana seluruh episode pembuatan jenang disuguhkan kepada masyarakat sebagai pesta dan sebagai sumber kesejahteraan bagi seluruh masyarakat Desa kaliputu, khususnya dan seluruh masyarakat kabupaten Kudus pada umumnya. Selain realitas yang tersaji tersebut, terdapat fenomena menarik yang perlu dicermati dalam karnaval budaya tersebut, diantaranya adalah pertama, karnaval "tebokan" tidak hanya sekedar pesta rakyat, tetapi juga menjadi bagian 
penting dari program pemerintah, khususnya dalam mengemukakan tradisi local sebagai tujuan wisata sekaligus sebagai asset daerah. Maka dalam penyelenggaraanya selalu didukung oleh pemerintah daerah lewat pemerintah desa, selain oleh para pengusaha jenang.

Fenomena yang kedua adalah munculnya sosok tokoh yang menjadi panutan dan disegani dalam kehidupan bermasyarakat. Hal ini terekam dalam prosesi karnaval, dimana ada pihak atau tokoh penting yang memberikan tebok kepada barong sebagai symbol pemenuhan atas permintaan syeh Jangkung untuk membangunkan cucu Mbah Dempok. Tokoh yang memberikan tebok ini dipandang sebagai figure yang sangat disegani di Desa ini, dialah Kepala Desa Kaliputu. Ketokohan dari Kepala Desa ini tidak hanya ketika pegelaran karnaval dilaksanakan, tetapi di dalam kehidupan seharihari tokoh Kepala Desa ini diyakini mempunyai charisma yang lebih diantara warga masyarakat Desa Kaliputu.

Figure kepala Desa Kaliputu dalam hal ini dianggap sebagai ketua suku, menurut penuturan Bapak Suyadi sebagai Kepala Desa Kaliputu, "di sini saya dipanggil sebagai kepala suku"(pen). Panggilan itu juga berlaku dalam kehidupan sehari-hari. Selain dari itu, kepada Desa juga dianggap sebagai tokoh yang mempunyai kekuatan lebih, setiap perkataan dan nasehatnya mengandung daya magis yang dipercayai dapat terjadi hal yang tidak diinginkan jika dilanggar. Suatu ketika ada proyek pemasangan tower di dekat kelurahan untuk kepentingan jaringan komunikasi, pada saat adzan Dzuhur Kepala Desa mengingatkan pekerja untuk istirahat sejenak menghormati waktu Dzuhur tetapi pekerja itu mengabaikannya, maka selang beberapa saat, tower itu rubuh dan pekerja itu jatuh tersangkut di genting rumah warga hingga koma (pen). Lepas dari perkataan sang Kepala Desa atau kecerobohan si Pekerja, yang jelas kecelakaan tersebut dianggap oleh masyarakat sebagai hal yang besar atas kelebihan yang dimiliki oleh Kepala Desa Kaliputu.

Fenomena riil disekitar upacara "tebokan" yang ketiga adalah antusiasme pengusaha jenang dalam berpartisipasi melaksanakan kegiatan "tebokan" tersebut. Menurut penuturan seorang tokoh di Desa Kaliputu, "mereka (pengusaha) itu kalau diminta menyumbangkan lima tebok malah yang keluar sepuluh 
tebok"(pen). Hal ini menunjukkan bagaimana semangat pengusaha jenang dalam menyelenggarakan acara ini sangat kuat. Ada rasa bangga tatkala mereka bisa menyumbangkan hasil produksinya untuk kepentingan pesta rakyat ini, karena tebok dan hasil produksi jenang yang ditampilkan ini nantinya dibagi dan diperebutkan oleh penonton yang menikmati karnaval "tebokan".

Terlepas dari kepentingan yang ada dibalik semangat para pengusaha jenang tersebut dalam menyelenggarakan acara ini, terdapat satu kepercayaan bahwa acara "tebokan" tersebut dapat mendatangkan keuntungan yang melimpah. Terdapat "berkab" dalam karnaval tersebut, begitu kata sebagian pengusaha jenang di Desa Kaliputu, bahkan pengusaha jenang yang berada diluar Desa Kaliputupun ikut serta menyumbangkan hasi produksinya sebagai bentuk adanya ikatan sejarah atas produksi jenang sebagai usaha yang digelutinya. Suatu ketika ada seorang pengusaha yang tidak ikut serta dalam upacata tebokan, karena dianggap sebagai hal yang tidak perlu, maka setelah peristiwa itu terjadi, produksi jenang yang dihasilkan oleh pengusaha tersebut tidak diterima oleh pasar atau dikembalikan semuanya oleh pemesan, pada hal sudah dalam kemasan yang baik dan dalam jumlah yang besar.

\section{Ragam Makna Upacara Tebokan}

Di dalam karnaval "tebokan" terdapat beberapa symbol yang diperankan oleh beberapa tokoh yang menggambarkan betapa besar arti penting jenang bagi kehidupan warga kaliputu baik kehidupan material maupun spiritual. Pagelaran karnaval tersebut mengisyaratkan kejadian dimana seorang tokoh penyebar agama Islam di Kabupaten Kudus, yakni Sunan Kudus memberikan pesan yang syarat dengan makna kepada masyarakat, dari mulai bagaimana berhubungan dengan sang pencipta dengan segala kegaibannya, sampai bagaimana berhubungan dengan sesama manusia dalam proses pemenuhan kebutuhan ragawi.

Tanda (sign) atau pesan simbolik yang didemonstrasikan dalam karnaval "tebokan" tersebut memamg tidak serta merta dapat dimaknai secara seragam oleh khalayak, karena pemaknaan atas tanda selalu terkait dengan latar belakang pembaca tanda. Jika realitas budaya ini dianggap sebagai sebuah teks, maka pemaknaan atas teks 
tersebut tentu terkait dengan konteks. Dalam kajian hermeneutika, keberadaan atau eksistensi manusia ditentukan oleh bagaimana dia memahami dan memaknai tanda kehidupan. Bagi Hans Georg Gadamer, sorang ahli hermeneutika dari Jerman, didalam memaknai realitas ataupun teks, seorang penafsir harus menghidupkan atau memproduksi makna yang terkandung dalam teks tersebut, sehingga teks tersebut menjadi kaya makna (Atho, 2003:136).

Di dalam karnaval "tebokan" setidaknya terdapat beberapa tanda yang memuat pesan simbolik, diantaranya adalah pertama, tokoh masyarakat local yang dalam hal ini diwakili oleh sosok Mbah Dempok Soponyono. Mbah dempok adalah seorang figure yang disegani yang mempunyai hoby bermain burung dara pada masa itu. Kedua, tokoh ulama yang berdakwah dan mensyiarkan agama Islam, yang dalam hal ini berwujud Sunan Kudus, Syeh Ja'far Shodiq dan muridnya yakni Syeh Jangkung (Saridin). Ketiga, Miniatur Menara Kudus yang terbuat dari gundukan jenang yang dibentuk sedemikian rupa hingga menyerupai menara Kudus. Keempat, Miniatur Masjid. Kelima, iring-iringan pembawa tebok, dan keenam, prosesi pembuatan jenang.

Makna yang dapat dibaca dalam isyarat keberadaan tokoh Mbah Dempok adalah kebersahajaan dari seorang tokoh yang disegani masyarakat, dia sangat dekat dengan masyarakat, dia menyuakai apa yang masyarakat sukai, dan dia merasa tidak ada jarak dengan masyarakat awam pada umumnya. Tokoh yang seperti inilah yang menjadi dambaan dan impian warga masyarakat Desa Kaliputu, yakni tokoh yang bisa ngemong dan ngayomi masyarakat, sehingga memberikan rasa aman bagi banyak orang. Di dalam realitas masyarakat perkotaan tokoh yang seperti ini sangat jarang, karena ketokohan dalam alam yang rasional seringkali didapatkan dengan usaha yang rasional pula, yakni dengan rekayasa yang penuh perhitungan dengan dukungan material. Jika sudah demikian maka yang muncul adalah sosok tokoh yang mementingkan diri sendiri dan tidak peduli dengan kesengsaraan banyak orang.

Makna yang kedua yang diisyartakan dalam karnaval “ tebokan" adalah keberadaan seorang ulama. Ulama sebagai juru dakwah idealnya adalah sosok yang mendukung dari belakang apa yang menjadi kebijakan public, sepanjang kebijakan tersebut tidak 
melanggar syari'at. Seorang ulama harus bisa menjadi pengikut yang mendukung pimpinan atau menjadi pemimpin yang bisa dijadikan tauladan, bukan menjadi pengikut yang "cerewet", tetapi ketika dijadikan pemimpin tidak bisa memberi tauladan yang baik. Dalam idiom Jawa, menjadi ulama itu tidak "nungkak mbedidangi". (di belakang menjegal, di depan menghadang).

Selain itu keberadaan sosok Sunan Kudus dan Syeh Jangkung dalam urutan kedua dari iring-iringan rombaongan karnaval menunjukkan bahwa didalam berdakwah seorang Da'i haruslah memperhatikan keberadaan tokoh local sebagai mad'u. seorang Da'i bukanlah tokoh yang paling pintar dalam lapangan dakwah, tetapi dia hanyalah sebagai pembawa risalah yang mau tidak mau harus dikompromikan dengan masyarakat setempat sebagai medan dakwahnya. Maka menghormati apa yang menjadi kebanggaan penduduk local adalah sebuah keniscayaan agar masyarakat sebagai mad'u tidak anti pati terhadap da'i. Itulah yang ditunjukkan dalam iring-iringan karnaval "tebokan", bukan ulama yang tampil paling depan, tetapi tokoh lokallah yang pantas untuk di dahulukan.

Makna yang ketiga dari tanda yang diisyaratkan dalam karnaval "tebokan" adalah keberadaan symbol suci bagi masyarakat Kudus, yakni menara Kudus. Menara Kudus adalah sebuah penanda akan besarnya pengaruh Islam di Kabupaten Kudus. Menara juga menjadi ikon resmi pemerintah Daerah Kabupaten Kudus. Keberadaan Menara Kudus menjadi sebuah symbol bahwa semajumajunya peradaban yang sudah diraih di daerah Kabupaten Kudus, hendaklah tidak melupakan jasa besar penyiar agama di tanah Jawa bagian utara ini, yang situsnya menjadi kebanggaan masyarakat Kudus, sekaligus sebagai pengingat bahwa agama adalah dasar dari sebuah peradaban.

Makna yang keempat yang diisyaratkan dalam karnaval "tebokan" adalah keberadaan miniature masjid dalam iring-iringan karnaval. selain tempat suci bagi umat Islam, masjid juga memiliki makna religiusitas masyarakat yang terpancar lewat segala aktifitas duniawi. Masjid dianggap sebagai perlambang kedamaian dan keselamatan. Sebuah bangunan dimana seorang hamba berinteraksi dan bercengkrama dengan sang Khalik dalam posisi bersujud. 
Maka masjid dalam sintaksis bahasa arab adalah tempat untuk bersujud. Jadi keberadaan miniature masjid dalam karnaval tersebut menunjukkan bahwa warga Desa Kaliputu adalah masyrakat yang menjunjung tinggi religiusitas, baik ketika berada dimasjid maupun ketika berada di dalam proses pekerjaan.

Isyarat makna yang kelima dalam karnaval "tebokan" adalah pertunjukan iring-iringan tebok berisi jenang yang dibawa oleh putra putri warga Desa Kaliputu. Biasanya pembawa tebok ini di ambilkan dari siswa siswi sekolah dasar yang ada di desa Kaliputu. Pada perayaan tahun 2011 yang lalu iring-iringan tebok ini berjumlah seribu nampan, sehingga karnaval pada saat itu dikenal dengan parade seribu tebok. Iring-iringan tebok ini menunjukkan bahwa desa kaliputu adalah sentra produksi jenang, sekaligus cikal bakal makanan yang terbuat dari tepung ketan dan gula ini ada. Seperti desa produktif lainnya di Kabupaten Kudus, Desa Kaliputu merupakan Desa percontohan sebagai Desa yang mempunyai sentra produksi, seperti halnya Desa Padurenan juga sebagai sentra produksi kerajinan bordir.

Menurut penjelasan Kepala Desa Kaliputu, salah satu bukti bahwa Desa Kaliputu adalah desa Jenang adalah para pekerja pembuat jenang yang berada di luar desapun kebanyakan berasal dari Desa Kaliputu, bahkan generasi pertama produsen jenang terbesar di Kabupaten Kudus juga berasal dari Desa Kaliputu (pen). Secara tidak langsung pawai ini mewartakan kepada masyarakat bahwa kita harus bangga desa kita menjadi sentra produksi jenang yang mampu mengharumkan nama desa sekaligus membawa nama Kudus di kancah nasional bahkan internasional. Dengan perasaan bangga maka generasi muda di Desa kaliputu tidak sungkan atau malu melestarikan makanan tradisonal ini.

Gunungan yang terbuat dari jenang mengisyaratkan kemakmuran yang diperoleh masyarakat Desa Kaliputu didominasi oleh produksi jenang yang melimpah. Gunungan tersebut nantinya akan diperebutkan dan dibagi-bagikan kepada warga sebagai symbol rasa syukur kepada yang maha Esa atas limpahan rizki yang diberikanNya. Hal ini merupakan "bancakan" massal atau pesta rakyat, seperti halnya upacara grebeg di keraton Yogyakarta maupun keraton Surakarta. 
Isyarat makna keenam dalam pawai "tebokan" di Desa kaliputu adalah iring-iringan prosesi pembuatan jenang. Dalam iringiringan tersebut ada yang membawa linggis (entong panjang seperti dayung sampan), kawah (wajan besar), kalo (sejenis tampah dari niru), ember, dan parutan. Dalam kenyataannya alat-alat tradisonal tersebut masih digunakan oleh sebagian produsen sebagai alat memproduksi jenang, meskipun modernisasi dan industrialisasi telah merubah alat-alat tradisional tersebut dengan mesin-mesin elektrik dan elektronik, seperti yang digunakan oleh produsenprodusen besar dalam memproduksi jenang.

Pertunjukan di atas mengisyartkan bahwa masyarakat Desa Kaliputu mempunyai etos kerja yang sangat tinggi, sehingga dapat menjadikan Desa Kaliputu menjadi Desa yang makmur diantara desa-desa di Kabupaten Kudus. Dari data yang tertera dalam monografi desa menujukkan bahwa dari jumlah 2052 usia produktif, sebanyak 1824 orang bekerja di sector usaha dan wiraswasta. Hal ini berarti dari 2050 pekerja, 90\% adalah bekerja di sector swasta yang produktif. Etos kerja yang tinggi tersebut tidak bisa dilepaskan dari konstruksi budaya yang sudah terbentuk melalui perpaduan antara mitos dan spirit agama, sehingga membentuk budaya kerja yang sangat produktif.

Isyarat makna yang terakhir adalah iring-iringan drum band dan karya seni lainya sebagai penanda bahwa sekarang adalah waktunya berpesta, sekarang adalah waktunya orang senang dan bahagia dengan berbagai pertunjukan seni dari mulai barongan sampai rebana. Dalam pawai kesenian tersebut dapat dibaca secara jelas bahwa ada perpaduan antara seni tradisional dengan seni modern, bahkan tradisi agama. Seni tradisional diwakili oleh rombongan seni barongan, sementara seni modern di wakili oleh rombongan drum band, dan seni religious diwakili oleh rombongan rebana yang melantunkan shalawat nabi oleh para punggawa-punggawa seni tersebut.

\section{Mitos, Agama, dan Kultur dalam Karnaval Tebokan}

Corak keberagamaan yang dilakukan oleh masyarakat Desa Kaliputu, tentu saja tidak seperti keberagamaan yang skriptualis, tetapi sebuah corak keberagamaan yang kontekstual, yaitu suatu cara beragama yang sudah membaur dengan budaya dan tradisi 
local, yakni sebuah corak keberagamaan yang cukup dinamis dalam berdialog dengan budaya local. Agama dalam konteks ini lalu dipandang sebagai sebuah system makna yang membimbing manusia menuju kebahagiaan di dunia dan di akhirat. Dengan corak keberagamaan yang seperti inilah terjadi peluang berkelindanya mitos, agama, dan kultur kontemporer dalam satu arena. Hal itu tercermin dalam parade kebudayaan yang disebut karnaval "tebokan".

Dalam kajiannya tentang agama, Clifford Geertz menguraikan tentang makna agama yang berarti suatu system symbol yang bertindak untuk memantapkan perasaan-perasaan ( moods) dan motivasi-motivasi secara kuat, menyeluruh, dan bertahan lama pada diri manusia, dengan cara memformulasikan konsepsi-konsepsi mengenai hukum (order), yang berlaku umum berkenaan dengan eksistensi manusia. Konsepsi-konsepsi ini selalu diselimuti dengan suatu aura tertentu yang mencerminkan kenyataan, sehingga perasaan-perasaan dan motivasi-motivasi tersebut nampak unik dan nyata (Geertz, 1973: 87).

Keberagamaan masyarakat Desa Kaliputu mungkin tidak sama dengan apa yang jabarkan oleh Geertz di atas, karena beragama bagi masyrakat ini tidak hanya sekedar motivasi yang memformulasikan aturan-aturan (order) tetapi aturan-aturan tersebut sudah menjadi baku ketika masyarakat sekarang ada, baru kemudian ada aturanaturan yang baru yang kemudian berkelindan menjadi sebuah norma yang dipakai oleh masyarakat luas. Yang membedakan adalah formal dan tidaknya aturan tersebut sehingga memberikan aksentuasi yang berbeda dalam melaksanakan aturan-aturan tersebut.

Kelindan antara system makna dan sistem nilai dalam proses dialektikanya tercermin dari bagaimana mitos Mbah Dempok yang menjadi tokoh sentral dalam masyarakat Kaliputu dengan segala kultur yang manaunginya bertemu dengan system nilai yang ditawarkan oleh ajaran Islam yang lembut, sehingga melahirkan dialog yang intensif dari generasi ke generasi. Pada tataran inilah muncul tata nilai yang lebih baru dari setiap generasi.

Persoalan selanjutnya adalah bagaimana setiap generasi tersebut menampilkan etos baru yang produktif dalam membangun peradaban, dan bagaimana strategi yang dilakukan oleh agen budaya dalam mempertahankan relasi tersebut adalah persoalanpersoalan yang terus dihadapi oleh setiap generasi. Pada dasawarsa 
terkhir ini nampaknya persoalan-persoalan tersebut tidak menjadi problem berarti, karena spirit tebokan memberikan gairah baru dalam meningkatkan produktifitas masyarakat. Setidaknya ada tiga hal penting yang mempunyai andil besar dalam merekonstruksi spirit produktif dalam acara karnaval "tebokan".

Pertama, nilai religious yang menyokong berlangsungnya acara "tebokan". Hal tersebut tercermin dari tujuan yang diharapkan oleh penyelenggara, yakni sebagai ungkapan rasa syukur terhadap Tuhan yang maha Esa atas karunianya sehingga warga masyarakat mendapatkan kemakmuran lewat produksi jenang (pen). Selain itu pesta rakyat yang menampilkan gunungan dan rombongan tebok adalah bentuk shadaqah dari para pengusaha kepada warga masyarakat. Dua ungkapan yakni syukur dan shadaqoh ini cukup mewakili unsure agama dalam membentuk spirit produktif.

Kedua, mitos yang berkembang di masyarakat menggiring warga untuk selalu menjaga tradisi jenang dalam diri individu maupun masyarakat. Di dalam penuturannya, salah satu informan pengusaha mengatakan bahwa tebokan adalah acara yang harus selalu diadakan, karena bisa mendatangkan rizki yang melimpah, kalau sampai acara ini tidak diadakan maka akan ada kerugian material yang akan menimpa warga (pen). Sekilas pernyataan seperti di atas memang tidak rasional tetapi mitos yang berkembang mengatakan demikian, karena mitos sendiri diartikan sebagai sebuah angan-angan social dan cita-cita kolektif yang selalu menggerakkan sebagaian masyarakat (Jamil, 2005:181).

Nilai yang ketiga, adalah struktur dan kultur masyarakat yang membentuk spirit kerja secara turun temurun. Salah satu tokoh Desa kaliputu mengatakan bahwa :

antusiasme para pengusaha dalam acara tebokan dianggap sebagai kebanggaan tersendiri. Jika mereka dimintai sumbangan sepuluh tebok, umpamanya, maka yang keluar malah lima belas. (pen)

ungkapan tersebut menandakan bahwa sumbangan dalam acara karnaval tebokan adalah sebuah sarana untuk menunjukkan kepada khalayak tentang status social seseorang. Semakin besar sumbangan yang diberikan, maka semakin tinggi pula status sosial penyumbang, karena sumbangan adalah symbol kemakmuran. 
Cara seseorang untuk merepresentasikan dirinya sengan symbol sumbangan tersebut di maknai sebagai representasi symbol kebudayaan yang di belakangnya dipenuhi serentetan peristiwa dan kejadian kebudayaan yang membentuk pribadi bahkan struktur komunitas orang tersebut. Representasi symbol yang terjadi dalam kasus di atas merupakan salah satu bentuk atau cara bagaimana sebuah kelompok mengkomunikasikan makna identitas budaya kepada orang lain dalam menentukan posisi mereka dalam masyarakat inilah yang oleh Pierre Bourdieu disebut sebagai distingsi yang didasari oleh keseragaman habitus (Haryatmoko, 2003).

Reproduksi spirit produktif melaui proyek habitus ini dilakukan secara rumit dan epistemic. Salah satu hal yang dapat ditangkap dari proses reproduksi spirit tersebut adalah jenjang karir para pengusaha jenang, yang selalu di awali dari bekerja sebagai buruh atau pegawai dalam usaha jenang, kemudian berlanjut bekerja sebagai bagian pemasaran, dan yang terakhir ketika mereka sudah bisa membuka pasar lalu membuka usaha jenang secara mandiri.

Rentang waktu dari mulai menjadi buruh sampai membuka usaha sendiri tersebut memang tidak pendek. Dalam rentang waktu tersebut terjadi proses belajar yang "dianggap" secara natural mengajari seseorang bagaimana mengembangkan usaha, bagaimana laku batin yang dilakukan, sampai pada bagaimana mengembangkan pasar agar usaha jenang menjadi popular di masyarakat. Dalam konteks inilah lalu spirit ini bertemu dengan kultur kontemporer yang penuh dengan citra-citra banal dimana seorang pengusaha bisa mencitrakan produknya di depan public. Media massa dan media virtual telah menyediakan banyak peluang untuk menjadikan pengusaha jenang tersebut dikenal oleh masyarakat di jagat raya ini. Inilah yang dilakukan oleh salah satu pengusaha jenang terbesar di Kabupaten Kudus yang merupakan generasi ketiga dari leluhurnya.

\section{Konsekwensi atas Segmentasi Pemaknaan Tradisi Tebokan}

Jika dicermati dalam segmentasi pemaknaan di dalam uraian di atas maka terdapat tiga kategori besar masyarakat dalam memaknai karnaval "tebokan". Pertama, kelompok pengusaha yang menjadikan tradisi ini sebagai bagian dari promosi produk yang dihasilkan dari Desa Kaliputu. Kepedulian atas acara ini terlihat jelas dari partisipasi 
maksimal dalam acara ini. Kedua, kelompok elit masyarakat yang memaknai tradisi tebokan sebagai ajang penegasan identitas local yang mampu berbicara dalam kontes global. Hal ini menjadi penting untuk dilakukan karena kebanggan akan identitas dan produk local akan menjadikan masyarakat menjadi tidak malu untuk melakukan aktifitas yang menjadi kebanggaaan daerah, yakni produsen jenang. Yang ketiga, golongan masyarakat awam yang memaknai tradisi tebokan sebagai arena perjuangan kelas dan suatu ajang dimana ketika seseorang ingin diakui keberadaannya maka ia harus mampu berkiprah dan mempunyai kontribusi pada acara karnaval tersebut.

Produk dari pemaknaan dan respon yang tersegmentasi terhadap karnaval "tebokan tersebut melahirkan tiga spirit produktif, yaitu pertama, makna advertising yang muncul dari karnaval budaya ini membangkitkan para pengusaha untuk lebih besar dalam berpartisipasi menggerakkan tradisi "tebokan". Semakin besar antusiasme peneyelenggara karnaval maka, semakin besar eksistensinya di dalam kancah peradaban, dan semakin besar eksistensi sebuah advertising maka semakin naik produksi yang siap diterima oleh pasar.

Kedua, Kebanggaan terhadap identitas local yang dipancarkan oleh elit local menjalar ke seluruh patron masyarakat sehingga otentisitas produk local semakin kelihatan. Hal ini dapat membangkitkan kebanggaan tersendiri bagi masyarakat luas sehingga mereka tidak malu dalam melakukan aktifitas produksi jenang. Selain itu karena terdapat perjuangan untuk mendapatkan legitimasi publik, maka pengukuhan eksistensi elit local menjadi sesuatu yang penting untuk dilakukan. Oleh karena itu spirit menjaga tradisi dan membimbing masyarakat untuk selalu melakukan regenerasi semakin kuat dilakukan oleh elit local.

Ketiga, pemaknaan karnaval tebokan sebagai arena perjuangan kelas, dapat membangkitkan semangat masyarakat awam untuk selalu berjuang agar dapat menjadi bagian penting dalam penyelenggaraan karnaval tebokan. Spirit inilah yang kemudian memunculkan etos kerja yang sangat tinggi dikalangan masyarakat Desa Kaliputu. Secara tidak langsung terdapat relasi strategis antara makna religious yang dipancarkan oleh elit agama, pemaknaan 
mitis yang dipancarkan oleh elit local bersama masyarakat awam, dan pemaknaan kultur kontemporer yang dibawa dan dipancarkan oleh elit ekonomi.

\section{Kesimpulan}

Mitos dalam kajian semiologi mungkin berbeda dengan mitos yang selama ini kita pahami sebagai sebuah angan-angan social dan citacita kolektif yang selalu menggerakkan sebagaian masyarakat atau seperti apa yan dipahami Malinowski, media pengungkapan dan merumuskan kepercayaan, melindungi dan memperkuat moralitas, menjadi efisiensi dan ritus, serta memberi peraturan praktis menuntun manusia. Mitos dalam semiologi tidak hanya sekedar persoalan world views masyarakat, system kepercayaan, atau ideology, seperti yang dijelaskan oleh Ralp Schroeder dalam membaca karya Max Weber (Schroeder,2002), tetapi mitos dalam semiologi adalah sebuah tipe wacana, yakni a social usage of language.

Keberadaan mitos dikendalikan secara cultural dan merupakan sebuah cerminan yang terbalik. Ia membalik sesuatu yang sesungguhnya bersifat cultural atau histories menjadi sesuatu yang seolah-olah alamiah. Secara sederhana mitos memuat makna-makna konotasi yang dicitrakan oleh sebuah objek, atau dalam definisi Roland Barthes diartikan sebagai wacana yang berkonotasi, wacana yang memasuki lapisan konotasi dalam proses signifikansinya (Aminuddin, 2002: 95) . Dengan pemahaman yang seperti itu sebenarnya mitosmitos itu selalu ada di sekitar kita, yang menggiring pemaknaan kita menjadi sebuah tindakan yang bersifat citrawi.

Pemahaman makna mitos yang demikian itu menjadi sangat menarik ketika bersentuhan dengan tradisi-tradisi agama yang dibumbui dengan persoalan structural kebudayaan dan struktur sosiologis masyarakat. Karnaval "tebokan" yang diselenggarakan di Desa Kaliputu adalah sebuah ilustrasi kebudayaan dimana relasi antara mitos, tradisi agama, dan struktur social mampu menggerakkan spirit produktif masyarakat desa Kaliputu sebagai sentra produksi Jenang di Kabupaten Kudus. Kearifan dalam meletakkan dialektika antara kultur lokal dan agama menjadikan sebuah corak budaya yang dinamis seiring dengan ritme kultur 
kontemporer. Ketiga system makna tersebut lalu menghadirkan tiga spirit penting dalam membangun produktifitas, yakni spirit inovatif, penegasan identitas, dan etos kerja.

\section{Daftar Pustaka}

Aminuddin, Faruk HT, I Dewa Putu Wijana, Kris Budiman, Melani Budianta. 2002. Analisis Wacana, dari Analisis sampai Dekonstruksi, Yogyakarta: Pusat Studi Kebudayaan UGM dan Kanal.

Barthes, Roland. 2007. Roland Barthes, Membedab Mitos-mitos Budaya Massa,Semiotika atau Sosiologi Tanda,Simbol, dan Representasi, Yogyakarta: Jalasutra.

Budiman, Hikmat. 1998. Pembunuhan yang Selalu Gagal, Yogyakarta: Putaka Pelajar.

Geertz, Clifford. 1973. Religion as A Cultural System, dalam The Interpretation of Culturer: Selected Essays by Clifford Geertz, New York: Anchor Chapter 4

Giddens, Anthony. 1999. A Phenomenology of Modernity, dalam Charles Lemert (Ed), Social Theory, The Multicultural and Classic Reading, Oxford: Westview Press.

Haryatmoko. 2003. Bourdieu/Menyingkap Kepalsuan Budaya Penguasa, BASIS, Tahun ke 52 November.

Jamil, M. Muhsin. 2005. Membongkar Mitos Menegakkan Nalar, Yogyakarta: Pustaka Pelajar.

Lemert, Charles (ed). 1999. Social Theory, The Multicultural and Classic Reading, Oxford: Westview Press.

Nasiful Atho' dan Arif Fahrudin (ed). 2003. Hermeneutika Transendental, dari Konfigurasi Filosofis menuju Praksis Islamic Studies, Yogyakarta: IRCISOD

Salim, Agus. 2001. Teori Dan Paradigma Penelitian Sosial: Dari Denzin Guba Dan Penerapannya, Yogyakarta: Tiara Wacana

Surachmad, Winarno. 1970. Dasar dan Tehnik Research: Pengantar Metodologi Ilmiah, Bandung: Tarsito

Ralph, Schroeder. 2002. MaxWeber, Tentang Hegemoni Sistem Kepercayaan, Yogyakarta: Kanisus

Vredenberg., Jacob. 1986. Metode dan Teknik Penelitian Masyarakat, Jakarta: Gramedia

Woodward, Mark. 1999. Islam Jawa, Kesalehan Normatif Versus Kebathinan, Yogyakarta : LKiS 